\title{
Reliability of cyclin A assessment on tissue microarrays in breast cancer compared to conventional histological slides
}

\author{
K Aaltonen ${ }^{*, 1,4}$, C Ahlin ${ }^{2,5}$, R-M Amini ${ }^{3}$, L Salonen ${ }^{4}$, M-L Fjällskog ${ }^{5}$, P Heikkilä6, H Nevanlinna ${ }^{5}$ \\ and $C$ Blomqvist ${ }^{1,5}$
}

'Department of Oncology, Helsinki University Central Hospital, PO Box 180, FIN 00290 HUS, Finland; ²Department of General Oncology, Örebro University Central Hospital, SE 70185 Örebro, Sweden; ${ }^{3}$ Department of Genetics and Pathology, Uppsala University Hospital, SE 75185 Uppsala, Sweden; ${ }^{4}$ Department of Obstetrics and Gynaecology, Helsinki University Central Hospital, PO Box 700, FIN 00029 HUS, Helsinki, Finland; ${ }^{5}$ Department of Oncology, Radiology and Clinical Immunology, Uppsala University Hospital, SE 75185 Uppsala, Sweden; ${ }^{6}$ Department of Pathology, Helsinki University Central Hospital, University of Helsinki, PO Box 21, FIN 00014 Helsinki, Finland

\begin{abstract}
Cyclin A has in some studies been associated with poor breast cancer survival, although all studies have not confirmed this. Its prognostic significance in breast cancer needs evaluation in larger studies. Tissue microarray (TMA) technique allows a simultaneous analysis of large amount of tumours on a single microscopic slide. This makes a rapid screening of molecular markers in large amount of tumours possible. Because only a small tissue sample of each tumour is punched on an array, the question has arisen about the representativeness of TMA when studying markers that are expressed in only a small proportion of cells. For this reason, we wanted to compare cyclin A expression on TMA and on traditional large sections. Two breast cancer TMAs were constructed of 200 breast tumours diagnosed between 1997-1998. TMA slides and traditional large section slides of these 200 tumours were stained with cyclin A antibody and analysed by two independent readers. The reproducibility of the two readers' results was good or even very good, with kappa values $0.7 \mathrm{I}-0.87$. The agreement of TMA and large section results was good with kappa value $0.62-$ 0.75. Cyclin A overexpression was significantly $(P<0.00 \mathrm{I})$ associated with oestrogen receptor and progesterone receptor negativity and high grade both on TMA and large sections. Cyclin A overexpression was significantly associated with poor metastasis-free survival both on TMA and large sections. The relative risks for metastasis were similar on TMA and large sections. This study suggests that TMA technique could be useful to study histological correlations and prognostic significance of cyclin A on breast cancer on a large scale.
\end{abstract}

British Journal of Cancer (2006) 94, 1697-1702. doi:I0.1038/sj.bjc.6603।47 www.bjcancer.com

Published online 2 May 2006

(c) 2006 Cancer Research UK

Keywords: breast cancer; cyclin A; tissue microarray

Breast cancer is a heterogeneous disease. Differences in tumour phenotypes lead to varying aggressiveness and ability to respond to a given treatment. Nowadays, breast tumours are classified not only by their morphological but also by immunohistochemical and molecular genetic characteristics.

Tissue microarray (TMA) technique was developed by Kononen et al (1998). This technique allows rapid screening of multiple stainings of large amount of tumours. In TMA technology, tissue cylinders (diameter $0.6 \mathrm{~mm}$ ) are punched from hundreds of different tumour blocks and brought into a recipient TMA block. Sections of the blocks can then be used in simultaneous analysis of all the tumours on DNA, RNA and protein level. Tissue microarray technique only takes out a small, cylindrical specimen from the donor block. This minimises the tissue damage to the donor block and allows its use in many studies, but still leaves a virtually undamaged tissue block for the pathologist.

*Correspondence: Dr K Aaltonen; E-mail: kirsimari.aaltonen@helsinki.fi Received 21 November 2005; revised 28 March 2006; accepted 5 April 2006; published online 2 May 2006
In TMA, only a small amount of tumour $(0.6 \mathrm{~mm})$ is analysed, leading to the question of how representative the minute tissue on TMA is and how much tumour heterogeneity affects the results. Many studies have shown that although a result of an individual tumour on TMA and on a large section may vary, the correlation to histopathological factors and prognostic implications are similar when large numbers of tumours are studied (Kononen et al, 1998; Camp et al, 2000; Gillett et al, 2000; Nocito et al, 2001; Torhorst et al, 2001). In breast cancer, the expression of known prognostic and predictive factors such ER (oestrogen receptor), PR (progesterone receptor) and HER2 (human epidermal growth factor receptor 2) were reliably analysed on TMA (Kononen et al, 1998; Camp et al, 2000; Gillett et al, 2000; Torhorst et al, 2001), but it is still unclear as to how representative TMA is when molecules that show focal localisation within the tumour are studied (Gillett et al, 2000).

More than $80 \%$ of breast cancer patients are alive 5 years after the initial diagnosis (Finnish Cancer Registry, 2002). The best established prognostic factors are tumour size and the number of the involved regional lymph nodes (Singletary et al, 2003). Grade of the tumour, hormone receptor (ER, PR) status and proliferation rate are also well-documented prognostic factors, especially in node-negative 
disease (Ross and Fletcher, 1999; Schnitt, 2001). Of these factors, only ER, PR and proliferation rate predict treatment efficacy. Expression of ER or PR is a prerequisite for endocrine responsiveness (EBCTCG, 2005), whereas a high proliferation rate predicts a more favourable chemotherapy response (Hietanen et al, 1995).

The best documented method of measuring proliferation in breast cancer is SPF (S-phase fraction) assessed by flow-cytometry (Sigurdsson et al, 1990). The method is, however, cumbersome and requires fresh tissue. In recent years, immunohistochemistry has gained popularity for the assessment of proliferation. Ki-67 is the most studied proliferation antigen, but there still is no consensus on methodology or cutoff values for prognostification in breast cancer (Colozza et al, 2005). Cyclins are cell cycle regulators overexpressed in several tumours including breast cancer (Parwaresch and Rudolph, 1996). Cyclin A is required for replication during the $S$-phase and is also expressed in the early mitotic phase (G2) of the cell cycle controlling the cell entry into mitosis (Parwaresch and Rudolph, 1996). In three previous studies in sarcomas and head and neck cancer, cyclin A was associated with prognosis and chemotherapy response even stronger than Ki-67 (Huuhtanen et al, 1999a, b; Saarilahti et al, 2003). Several studies have shown an association between overexpression of cyclin A and poor survival in breast cancer (Bukholm et al, 2003a, b, 2001; Michalides et al, 2002; Michels et al, 2003), whereas one study did not confirm it (Kuhling et al, 2003; Rudolph et al, 2003). Further studies with a larger number of patients are needed, including also specific groups of patients like those with hereditary predisposition to breast cancer. Tissue microarray seems a tempting method to evaluate cyclin A expression on breast tumours. Cyclins D1 and E have been studied on TMA (Richter et al, 2000; Han et al, 2003; Hedberg et al, 2003; Jirstrom et al, 2003; Schraml et al, 2003; Stendahl et al, 2004). However, cyclin A has not yet been analysed on breast cancer TMA. In this study, we evaluated cyclin A expression of 200 breast tumours on TMA and large sections in order to evaluate the representativity of TMA for the assessment of proliferation compared to large sections.

\section{MATERIALS AND METHODS}

\section{Patients}

Tumours from 200 breast cancer patients, treated in Helsinki University Central Hospital between 1997 and 1998 (Syrjakoski et al, 2000), were analysed on TMA and traditional large sections. Pathology reports of the primary tumours were studied. Pathological data including information on tumour histology, grade, ER and PR status, tumour diameter, nodal status and distant metastases were collected. Grading was performed according to Scarff-BloomRichardson modified by Elston and Ellis (1991). Patients' records were studied and information on adjuvant treatment, local relapse and distant metastases as well as time of death or follow-up were collected. Patient characteristics are shown in Table 1.

\section{Tissue microarray construction}

Paraffin blocks of primary tumours of the patients were collected. Haematoxylin and eosin sections of the original blocks were studied and the most representative area of each tumour was punched and brought into two recipient paraffin blocks to produce two breast cancer microarrays, including four cores (diameter $0.6 \mathrm{~mm}$ ) of each tumour. Then, 3- to $4-\mu \mathrm{m}$ - thick sections were then cut from array blocks and transferred to glass slide (Eerola et al, 2005; Tommiska et al, 2005).

\section{Immunohistochemistry}

Formalin-fixed paraffin-embedded tissue material from the blocks used for TMA sampling from each of the 200 tumours and their
Table I Patient characteristics

\begin{tabular}{|c|c|c|c|}
\hline \multicolumn{2}{|l|}{ Grade } & \multicolumn{2}{|c|}{$T$} \\
\hline I & $47(23.5 \%)$ & । & | | | (55.5\%) \\
\hline 2 & $86(43.0 \%)$ & 2 & $71(35.5 \%)$ \\
\hline 3 & $58(29.0 \%)$ & 3 & $6(3.0 \%)$ \\
\hline \multirow[t]{2}{*}{ Not known } & $9(4.5 \%)$ & 4 & $7(3.5 \%)$ \\
\hline & & Not known & $5(2.5 \%)$ \\
\hline \multicolumn{2}{|l|}{$N$} & \multicolumn{2}{|c|}{ M } \\
\hline Node positive & $96(48.0 \%)$ & 0 & $190(95.0 \%)$ \\
\hline Node negative & $98(49.0 \%)$ & I & $9(4.5 \%)$ \\
\hline Not known & $6(3.0 \%)$ & Not known & $(0.5 \%)$ \\
\hline \multicolumn{2}{|l|}{ Oestrogen receptor } & \multicolumn{2}{|c|}{ Progesterone receptor } \\
\hline Positive & I 55 (77.5\%) & Positive & 137 (68.5\%) \\
\hline Negative & $35(17.5 \%)$ & Negative & $53(26.5 \%)$ \\
\hline Not known & $10(5.0 \%)$ & Not known & $10(5.0 \%)$ \\
\hline \multicolumn{2}{|l|}{ Local relapse } & \multicolumn{2}{|c|}{ Distant metastases } \\
\hline Yes & $22(11.0 \%)$ & Yes & $49(24.5 \%)$ \\
\hline No & $178(89.0 \%)$ & No & | 51 (75.5\%) \\
\hline \multicolumn{2}{|c|}{ Adjuvant radiotherapy } & \multicolumn{2}{|c|}{ Adjuvant chemotherapy } \\
\hline Yes & 173 (86.5\%) & Yes & $78(39.0 \%)$ \\
\hline No & $27(13.5 \%)$ & No & $122(61.0 \%)$ \\
\hline \multicolumn{4}{|c|}{ Adjuvant hormone therapy } \\
\hline Yes & $91(45.5 \%)$ & & \\
\hline No & $109(54.5 \%)$ & & \\
\hline
\end{tabular}

corresponding TMA slides were cut in 3- to $4-\mu \mathrm{m}$-thick sections and deparaffinised. Immunostaining for cyclin A (mouse monoclonal; Novo Castra Laboratories) was carried out manually. Antigen retrieval was carried out using a pressure cooker for $5 \mathrm{~min}$ in $0.01 \mathrm{M}$ citrate buffer, $\mathrm{pH}$ 6.0. Primary antibody was diluted $1: 300$ and applied for overnight incubation. Staining was carried out using the avidin-biotin peroxidase complex and AEC procedures (Wood and Warnke, 1981). The peroxidase was developed using the DAB technique.

Two readers (KA and CA) scored all slides. The percentage of cyclin A-positive breast cancer cells was counted in one highpower field ( $\times 40$ objective) in each of the four tissue cores on TMA and in three randomly selected and one 'hot-spot' highpower field on large sections. A minimum of 200 breast cancer cells and in most cases at least 400 breast cancer cells were counted from each tumour. To better demonstrate the pathological associations, results were dichotomised at a cutoff value of $10 \%$ (Poikonen et al, 2005). All statistical evaluations were carried out with both average and maximal values of the four counts.

\section{Statistical analysis}

All statistical analyses were made using Macintosh SPSS 11 statistical software package. Correlations of TMA and large section results as well as correlations of two independent readers' results were evaluated by crosstabs and by a scatter diagram showing the differences of the results plotted against the average of the results. Kappa values were counted to evaluate the reproducibility of the results by two readers and by two different methods. Student's $t$ test for independent samples was used to analyse whether disconcordant results on large section and TMA or between the two readers was owing to a low number of cells counted. Correlation of cyclin A expression to ER, PR, nodal status and grade were analysed by the nonparametric Spearman's correlation coefficient. All statistical tests of the association of cyclin A and clinical parameters as well as survival analysis with the Cox proportional-hazard model were performed with cyclin A percentage as a continuous variable. To improve readability, relative risks 
for metastasis or death was calculated for cyclin A dichotomised at a cutoff of $10 \%$.

\section{RESULTS}

On TMA, results of 14 tumours (7\%) were missing, five of them owing to loss of all four punches during the staining and nine because of lack of tumour in the arrayed samples. On large sections, result of only one tumour $(0.5 \%)$ was missing, and the reason was unsuccessful staining. The median cyclin A count $3.7 \%$ (range $0-34.4 \%$ ) on TMA average values, $5.8 \%(0-52.9 \%)$ on TMA maximum values, $4.3 \%(0-32.1 \%)$ on large section average values and $9.0 \%(0-39.1 \%)$ on large section maximum values.

\section{Agreement of readers' results}

Figures 1 and 2 show scatter diagrams of the differences of two readers' results. The mean difference between the two readers scoring and $95 \%$ limits of agreement were $0.1 \%(-4.8$ to $+5.1 \%)$ for TMA average values, $0.4 \%(-8.0$ to $+8.8 \%)$ for TMA maximum values, $0.4 \%(-4.4$ to $+5.1 \%)$ for large section average values and $1.0 \%(-7.5$ to $+9.5 \%)$ for large section maximum values. The kappa values evaluating the reproducibility two readers' results were 0.87 for TMA average value, 0.83 for TMA maximum value, 0.71 for large section average value and 0.80 for large section maximum value. The concordance of the positive and the negative results for the two readers with $10 \%$ as a cutoff point is shown in Table 2. In order to evaluate possible reasons for discrepant results of the two readers, we calculated the mean number of nuclei counted for concordant $v s$ discrepant cases. The mean number is the mean of the two readers results. The mean number of nuclei counted was 661 in concordant tumours and 420 in discrepant tumours $(P=0.002)$ for array average values, 671 in concordant tumours and 410 in discrepant tumours $(P<0.0005)$ for array maximum values, 767 in concordant tumours and 465 in discrepant tumours $(P<0.0005)$ for large section average values and 759 in concordant tumours and 518 in discrepant tumours for large section maximum values $(P<0.0005)$.

\section{Agreement of TMA and large sections on cyclin A staining}

Tissue microarray and large section cyclin A results were compared using the average values of the two readers' results. Figure 3 shows a scatter diagram of the differences of TMA and large section results. The mean difference between the TMA and large section scoring and 95\% limits of agreement were $0.4 \%(-6.9$ to $+7.6 \%)$ for average values and $2.0 \%(-8.7$ to $+12.6 \%)$ for maximum values. The kappa values were 0.75 for average values and 0.62 for maximum values. The agreement for classification of a high cyclin A score between TMA and sections is shown in Table 3. The mean amount of nuclei counted was 683 in concordant tumours and 308 in discrepant tumours for average values $(P<0.0005)$. For maximum values, the mean amount of cells counted in concordant tumours was 661 and 612 in discrepant tumours $(P=0.33)$.

When associations of cyclin $\mathrm{A}$ and histological variables were studied, the results on TMA and large sections were well in concordance. High cyclin A expression associated strongly with ER negativity $(P<0.0005)$, PR negativity $(P<0.0005)$ and high grade $(P<0.0005)$. The associations were similar when cyclin A expression was analysed with TMA maximum value, TMA average value, large section maximum value and large section average value (Table 4). Cyclin A expression was not associated with nodal status of the tumour.

Cyclin A overexpression was not statistically significantly associated with overall survival; however, it was significantly associated with poorer metastasis-free survival (Table 5).
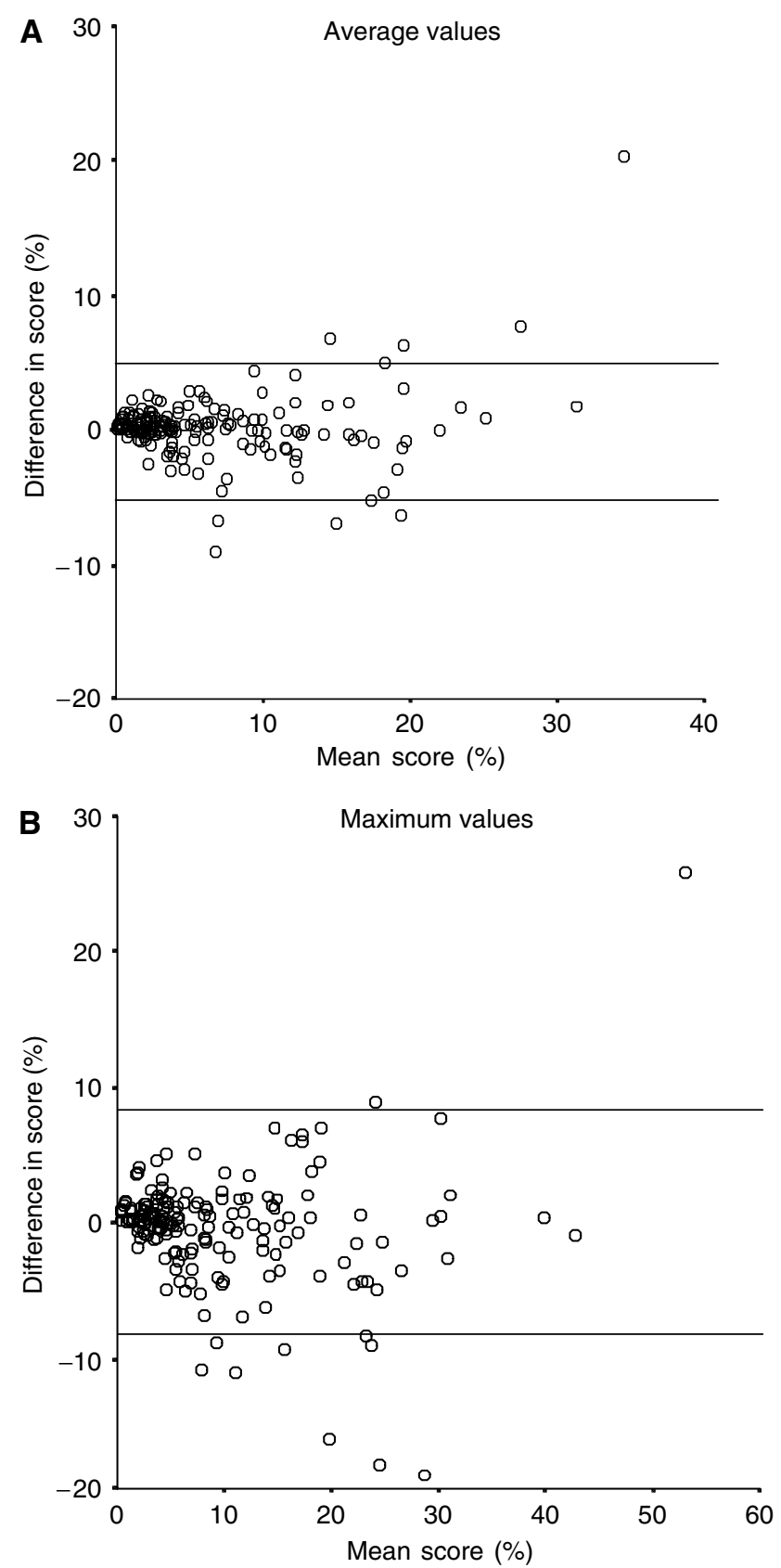

Figure I (A) Scattergram shows the difference in two readers score (KA-CA) compared to mean score of the two readers $(K A+C A / 2)$ on TMA average values. Lines indicate the 95\% limits of agreement. (B) Scattergram shows the difference in two readers score (KA-CA) compared to mean score of the two readers $(K A+C A / 2)$ TMA maximum values. Lines indicate the $95 \%$ limits of agreement.

\section{DISCUSSION}

In this study, we investigated cyclin A expression of 200 breast tumours on TMA and on traditional large sections and we found that the agreement between these methods is good, as well as the reproducibility of the results by two independent readers. The main aim of this study with a relatively small patient population of 200 patients was to evaluate the suitability of TMA analysis for a larger scale study on the prognostic significance of cyclin A and not to clarify the prognostic value of cyclin A overexpression. All histological correlations, however, were similar on TMA and large 

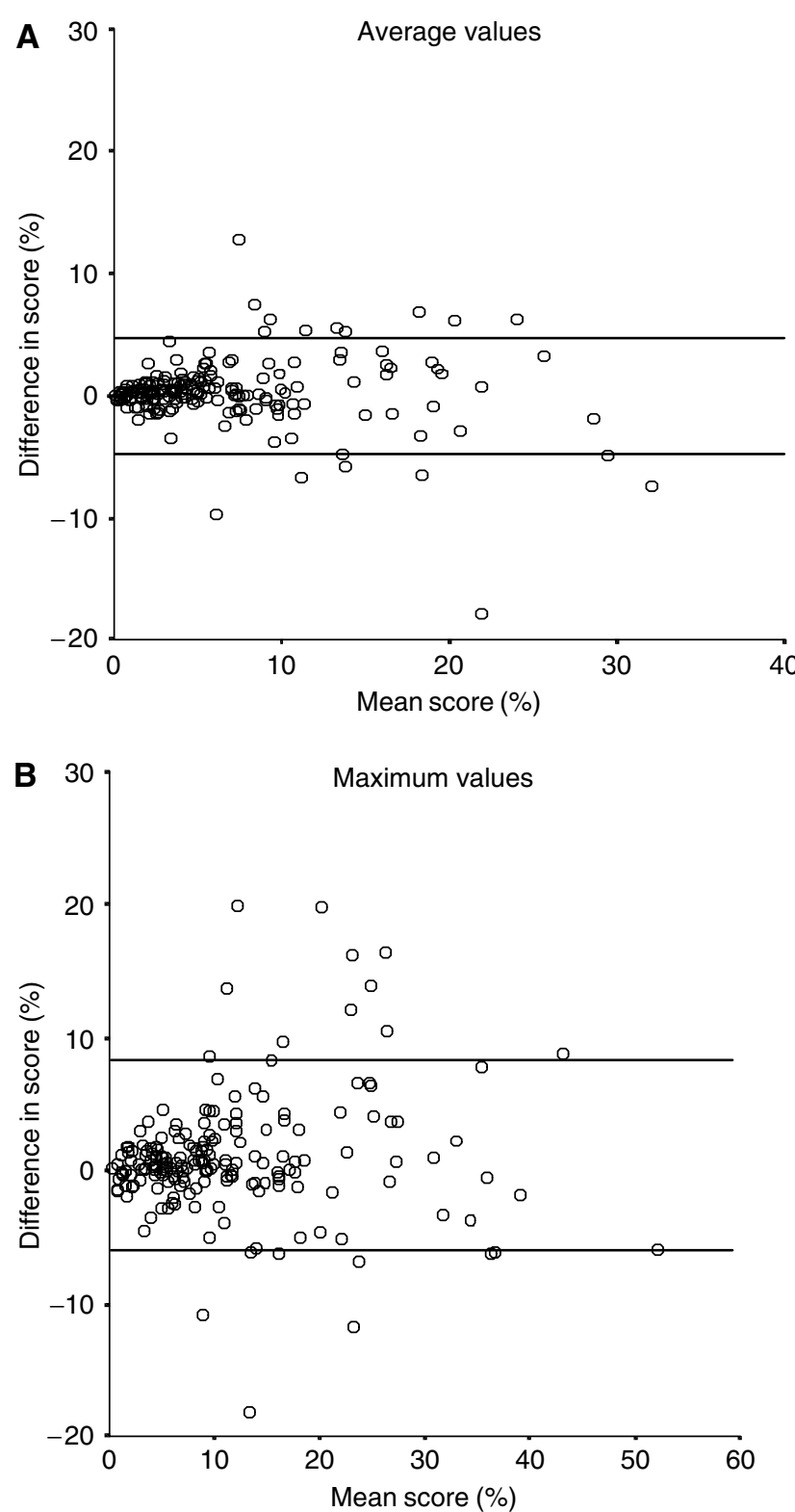

Figure 2 (A) Scattergram shows the difference in two readers score (KA-CA) compared to mean score of the two readers $(K A+C A / 2)$ on large section average values. Lines indicate the $95 \%$ limits of agreement. (B) Scattergram shows the difference in two readers score (KA-CA) compared to mean score of the two readers $(K A+C A / 2)$ on large section maximum values. Lines indicate the $95 \%$ limits of agreement.

section. The results suggest that relative risks for overall and metastasis-free survival can be evaluated on TMA as reliably as on large sections.

To evaluate the reproducibility of cyclin A results, we first compared the agreement of two readers' results. The kappa value is considered as a reliable tool to assess this agreement (Altman, 1991). The agreement is good if the kappa value is $0.61-0.80$ and very good if the kappa value is $0.81-1.00$ (Altman, 1991). We found the reproducibility of cyclin A assessment for the two readers to be good or very good both in large sections and TMAs. As expected, the assessment of maximum proliferation rate using hot-spots was less reproducible. One important reason for disagreement seems to be the amount of tissues studied, as discrepant findings seemed to be associated with low number of nuclei counted. In a recent study, the reproducibility of
Table 2 Comparison of the results of two independent readers

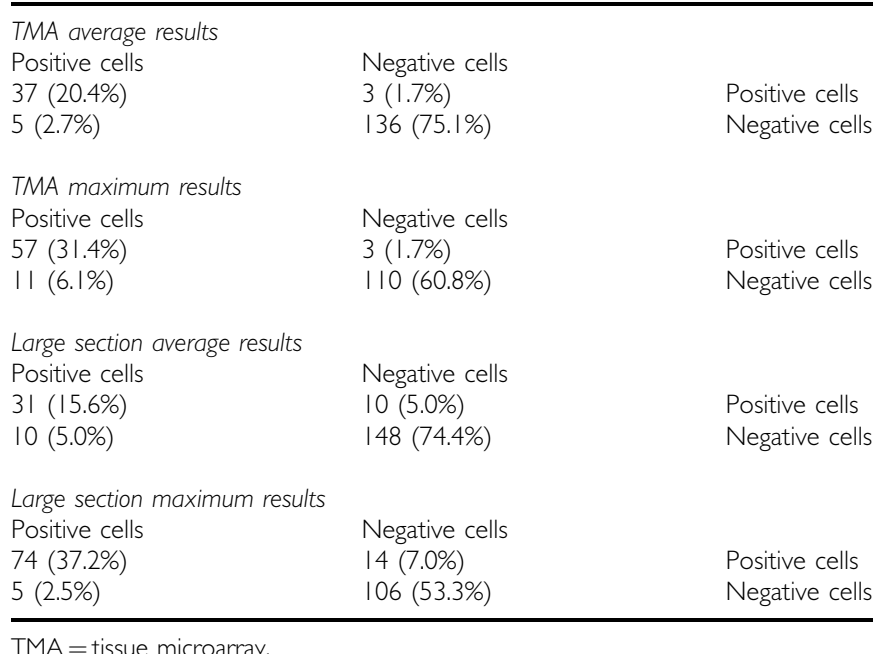

malignancy grading was only moderately good (Meyer et al, 2005), suggesting that measurement of proliferation by immunohistochemically detectable markers will probably give superior results. Our study shows that reproducibility of cyclin A expression on TMA is good and it seems to be a method that could easily be adapted to routine use.

As the results of two readers were in concordance, we counted the average of the results of two readers and used these results to analyse the concordance of TMA and large section results. The agreement between cyclin A assessment on TMAs and large slides was good for both mean and maximum value, but as expected somewhat better for the former. Again, the average results that differ most from each other were results of tumours with fewer cells counted. The agreement was moderately weaker on maximum than average values. One reason for this could be the method used in counting cells: on TMA, one randomly selected high-power field was counted on each punch, but on large sections, we searched one 'hot-spot' high-power field and selected the other three randomly. Earlier studies in breast cancer TMA have shown good agreement of ER, PR, p53 and HER2 between TMA and large sections (Camp et al, 2000; Gillett et al, 2000; Torhorst et al, 2001). Expression of cyclins E and D1 were in concordance in 94.3 and $95.4 \%$ of cases, respectively, in a previous study of 175 breast tumours (Han et al, 2003). The proliferation marker Ki-67 was studied in a previous bladder carcinoma study comprising 2317 cases and the concordance of TMA and large sections was good (Nocito et al, 2001). Cyclin E expression on TMA and large section has also been evaluated in a series of 218 renal cell carcinomas and the agreement was good $(P<0.001)$ (Hedberg et al, 2003).

Cyclin A overexpression was associated with ER and PR negativity and with high grade, in line with earlier studies (Michalides et al, 2002; Michels et al, 2003). A high cyclin A score was also prognostic for distant recurrence both in large sections and TMAs. Most previous studies have shown association between cyclin A overexpression and poor prognosis (Bukholm et al, 2001, 2003a; Michalides et al, 2002; Michels et al, 2003), whereas one study failed to find an association (Kuhling et al, 2003; Rudolph et al, 2003). Thus in concordance with other studies in various malignancies, this study confirms that TMAs are well suited for assessment of immunohistochemical markers even for antigens with a variable expression in different parts of a tumour. The similarity of clinicopathological associations on TMAs and large sections also support the validity of TMA for scoring of cyclin A in breast cancer.

Considering our results, we conclude that TMA is as good as large sections in scoring for cyclin A on breast cancer. 

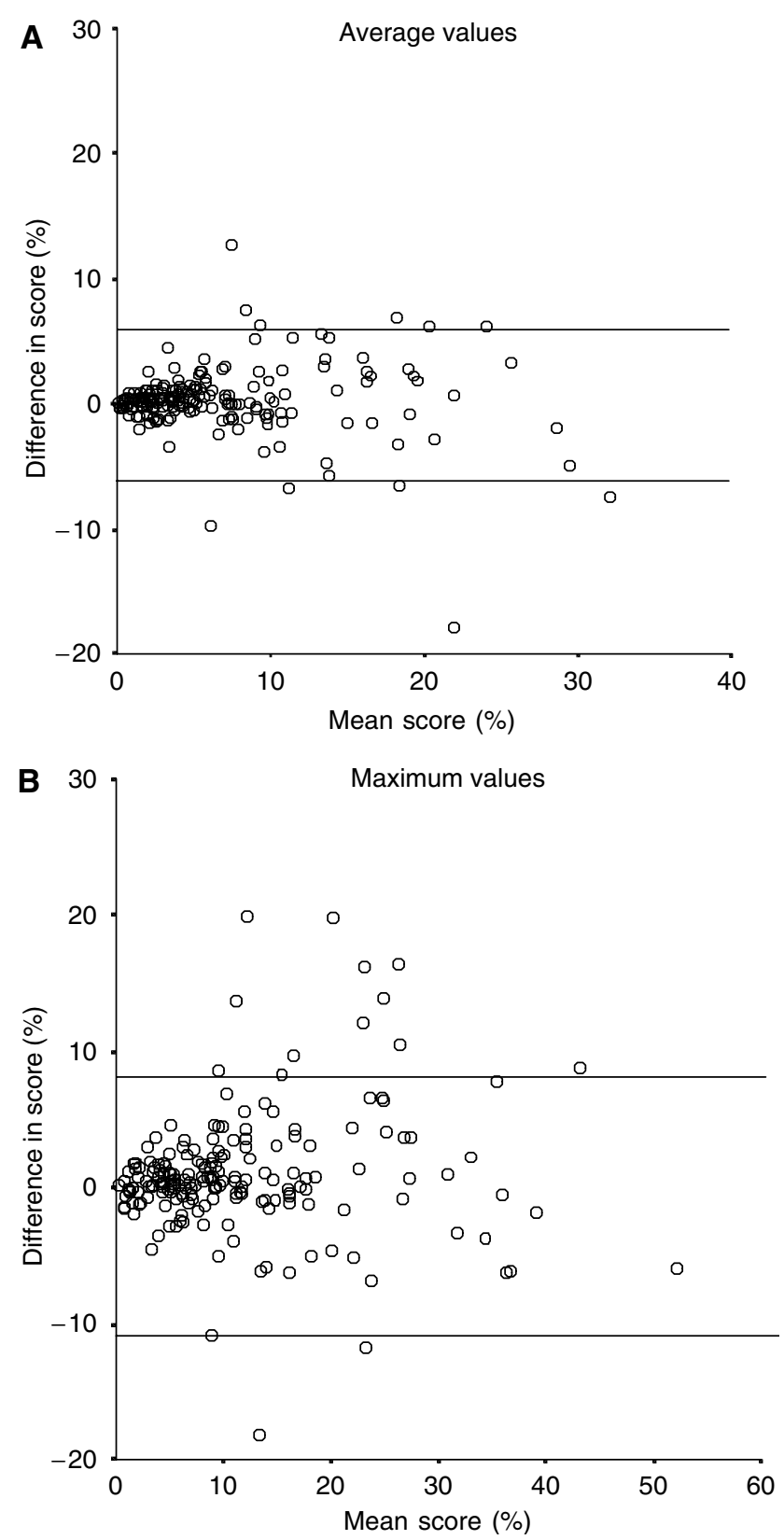

Figure 3 (A) Scattergram shows the difference in array and large section scores (array-large section) compared to large section score on average values. Lines indicate the 95\% limits of agreement. (B) Scattergram shows the difference in array and large section scores (array-large section) compared to large section score on maximum values. Lines indicate the 95\% limits of agreement.

Table 3 Comparison of tissue microarray and large section results

\section{Average results}

Array, positive cells Array, negative cells $30(16.1 \%)$

$7(3.8 \%)$

\section{$8(4.3 \%)$}

|4| (75.8\%)
Array, positive cells $53(28.5 \%)$ $7(3.8 \%)$
Maximum results
Array, negative cells

$27(14.5 \%)$ $99(53.2 \%)$
Large section, positive cells Large section, negative cells

Large section, positive cells Large section, negative cells
Table 4 Cyclin A and correlation to histological variables

\begin{tabular}{lll}
\hline & Spearman's correlation coefficient $\boldsymbol{P}$-value \\
\hline ER & & \\
TMA average value & -0.417 & $<0.0005$ \\
TMA maximum value & -0.414 & $<0.0005$ \\
Large section average value & -0.453 & $<0.0005$ \\
Large section maximum value & -0.459 & $<0.0005$ \\
PR & & \\
TMA average value & -0.427 & $<0.0005$ \\
TMA maximum value & -0.427 & $<0.0005$ \\
Large section average value & -0.474 & $<0.0005$ \\
Large section maximum value & -0.450 & $<0.0005$ \\
& & \\
Grade & & $<0.0005$ \\
TMA average value & 0.529 & $<0.0005$ \\
TMA maximum value & 0.537 & $<0.0005$ \\
Large section average value & 0.555 & $<0.0005$ \\
Large section maximum value & 0.523 & \\
Nodal status & & 0.295 \\
TMA average value & -0.078 & 0.384 \\
TMA maximum value & -0.065 & 0.539 \\
Large section average value & -0.046 & 0.762 \\
Large section maximum value & -0.023 & \\
\hline TMA = tissue microarray. & &
\end{tabular}

Table 5 Survival and cyclin A overexpression

\begin{tabular}{lcc}
\hline & Hazard for low vs high cyclin $\mathbf{A}^{\mathbf{a}} \mathbf{P}$-value \\
\hline & & \\
(a) Overall sunival & & \\
TMA average result & 1.338 & 0.128 \\
Large section average result & 1.205 & 0.639 \\
TMA maximum result & 1.651 & 0.173 \\
Large section maximum result & 1.393 & 0.755 \\
& & \\
(b) Overall sunvival in multivariate analysis with adjuvant chemotherapy and hormone \\
therapy & 1.580 & \\
TMA average result & 1.540 & 0.051 \\
Large section average result & 1.915 & 0.503 \\
TMA maximum result & 1.194 & 0.076 \\
Large section maximum result & & 0.534 \\
& & \\
(c) Metastasis free sunvival & 1.765 & 0.026 \\
TMA average result & 1.831 & 0.117 \\
Large section average result & 1.858 & 0.022 \\
TMA maximum result & 1.463 & 0.021 \\
Large section maximum result &
\end{tabular}

(d) Metastasis free survival in multivariate analysis with adjuvant chemotherapy and hormone therapy

$\begin{array}{lll}\text { TMA average result } & 2.100 & 0.009 \\ \text { Large section average result } & 1.950 & 0.075 \\ \text { TMA maximum result } & 2.149 & 0.009 \\ \text { Large section maximum result } & 1.528 & 0.019\end{array}$

a Low/high cut off value $10 \% .{ }^{b}$ Cyclin $\mathrm{A}$ analyzed as a continuous variable.

\section{ACKNOWLEDGEMENTS}

We thank Minna Merikivi and Nina Puolakka for excellent work with our patients and Majlis Book for skilful technical assistance. This study has been financially supported by grants from the Finnish-Norwegian Medical Foundation and from the Finska Läkaresällskapet (Finnish Medical Society), the Helsinki University Central Hospital Research Fund, Finnish Academy of Sciences, Finnish Cancer Society and Sigrid Juselius Foundation.

All patients participated in our study are gratefully acknowledged. 


\section{REFERENCES}

Altman DG (1991) Practical Statistics for Medical Research. London: Chapman \& Hall

Bukholm IR, Bukholm G, Holm R, Nesland JM (2003a) Association between histology grade, expression of HsMCM2, and cyclin A in human invasive breast carcinomas. J Clin Pathol 56: 368-373

Bukholm IR, Bukholm G, Nesland JM (2001) Over-expression of cyclin A is highly associated with early relapse and reduced survival in patients with primary breast carcinomas. Int J Cancer 93: 283-287

Bukholm IR, Husdal A, Nesland JM, Langerod A, Bukholm G (2003b) Overexpression of cyclin A overrides the effect of p53 alterations in breast cancer patients with long follow-up time. Breast Cancer Res Treat 80: $199-206$

Camp RL, Charette LA, Rimm DL (2000) Validation of tissue microarray technology in breast carcinoma. Lab Invest 80: 1943-1949

Colozza M, Azambuja E, Cardoso F, Sotiriou C, Larsimont D, Piccart MJ (2005) Proliferative markers as prognostic and predictive tools in early breast cancer: where are we now? Ann Oncol 16: $1723-1739$

EBCTCG (2005) Effects of chemotherapy and hormonal therapy for early breast cancer recurrence and 15-year survival: an overview of the randomised trials. Lancet 365: 1687-1717

Eerola H, Heikkila P, Tamminen A, Aittomaki K, Blomqvist C, Nevanlinna H (2005) Histopathological features of breast tumours in BRCA1, BRCA2 and mutation-negative breast cancer families. Breast Cancer Res 7: R93-R100

Elston CW, Ellis IO (1991) Pathological prognostic factors in breast cancer. I. The value of histological grade in breast cancer: experience from a large study with long-term follow-up. Histopathology 19: 403-410 Finnish Cancer Registry (2002) www.cancerregistry.fi

Gillett CE, Springall RJ, Barnes DM, Hanby AM (2000) Multiple tissue core arrays in histopathology research: a validation study. J Pathol 192: 549 553

Han S, Park K, Bae BN, Kim KH, Kim HJ, Kim YD, Kim HY (2003) Prognostic implication of cyclin E expression and its relationship with cyclin D1 and p27kip1 expression on tissue microarrays of node negative breast cancer. J Surg Oncol 83: $241-247$

Hedberg Y, Ljungberg B, Roos G, Landberg G (2003) Expression of cyclin D1, D3, E, and p27 in human renal cell carcinoma analysed by tissue microarray. Br J Cancer 88: 1417-1423

Hietanen P, Blomqvist C, Wasenius VM, Niskanen E, Franssila K, Nordling S (1995) Do DNA ploidy and S-phase fraction in primary tumour predict the response to chemotherapy in metastatic breast cancer? $\mathrm{Br} \mathrm{J}$ Cancer 71: $1029-1032$

Huuhtanen R, Blomqvist C, Bohling T, Wiklund T, Tukiainen E, Virolainen M, Tribukait B, Andersson L (1999a) Expression of cyclin A in soft tissue sarcomas correlates with tumor aggressiveness. Cancer Res 59: $2885-2890$

Huuhtanen R, Wiklund T, Blomqvist C, Bohling T, Virolainen M, Tribukait B, Andersson L (1999b) A high proliferation rate measured by cyclin A predicts a favourable chemotherapy response in soft tissue sarcoma patients. Br J Cancer 81: 1017-1021

Jirstrom K, Ringberg A, Ferno M, Anagnostaki L, Landberg G (2003) Tissue microarray analysis of G1/S-regulatory proteins in ductal carcinoma in situ of the breast indicate that low cyclin D1 is associated with local recurrence. Br J Cancer 17: 1920-1926

Kononen J, Bubendorf L, Kallioniemi A, Bärlund M, Schraml P, Leighton S, Torhorst J, Mihatsch MJ, Sauter G, Kallioniemi O-P (1998) Tissue microarrays for high-throughput molecular profiling of tumor specimens. Nat Med 4: 844-847

Kuhling H, Alm P, Olsson H, Fernö M, Baldetorp B, Parwaresch R, Rudolph P (2003) Expression of cyclins E, A, and B, and prognosis in lymph nodenegative breast cancer. J Pathol 199: 424-431

Meyer JS, Alvarez C, Milikowski C, Olson N, Russo I, Russo J, Glass A, Zehnbaur BA, Lister R, Parwaresch R (2005) Breast carcinoma malignancy grading by Bloom-Richardson system vs proliferation index: reproducibility of grade and advantages of proliferation index. Mod Pathol 8: $1-12$

Michalides R, van Tinteren H, Balkenende A, Vermorken JB, Benraadt J, Huldij J, van Diest P (2002) Cyclin A is a prognostic indicator in early stage breast cancer with and without tamoxifen treatment. $\mathrm{Br} J$ Cancer 86: $402-408$

Michels JJ, Duigou F, Marnay J, Henry-Amar M, Delozier T, Denoux Y, Chasle J (2003) Flow cytometry and quantitive immunohistochemical study of cell cycle regulation proteins in invasive breast carcinoma. Cancer 97: 1376 - 1386

Nocito A, Bubendorf L, Tinner EM, Suess K, Wagner U, Forster T, Kononen J, Fijan A, Bruderer J, Schmid U, Ackerman D, Maurer R, Alund G, Knönagel H, Rist M, Anabitarte M, Hering F, Hardmeier T, Schoenenberger AJ, Flury R, Jäger P, Fehr JL, Schraml P, Moch H, Mihatsch MJ, Gasser T, Sauter G (2001) Microarrays of bladder cancer are highly presentative of proliferation index and histological grade. J Pathol 194: $349-357$

Parwaresch R, Rudolph P (1996) The cell cycle - theory and applications in cancer. Onkologie 19: 464-472

Poikonen P, Sjöström J, Amini R-M, Villman K, Ahlgren J, Blomqvist C (2005) Cyclin A as a marker for prognosis and chemotherapy response in advanced breast cancer. $\mathrm{Br}$ J Cancer 93: 515-519

Richter J, Wagner U, Kononen J, Fijan A, Bruderer J, Schmid U, Ackermann D, Maurer R, Alund G, Knönagel H, Rist M, Wilber K, Anabitarte M, Hering F, Hardmeier T, Schönenberger A, Flury R, Jäger P, Fehr JL, Schraml P, Moch H, Mihatsch MJ, Gasser T, Kallioniemi O-P, Sauter G (2000) High-throughput tissue microarray analysis of cyclin E gene amplification and overexpression in urinary bladder cancer. Am J Pathol 157: $787-794$

Ross JS, Fletcher JA (1999) The HER-2/neu oncogene: prognostic factor, predictive factor and target for therapy. Semin Cancer Biol 9: 125-138

Rudolph P, Kuhling H, Alm P, Fernö M, Baldetorp B, Olsson H, Parwaresch R (2003) Differential prognostic impact of the cyclins $E$ and B in premenopausal and postmenopausal women with lymph node-negative breast cancer. Int J Cancer 105: 674-680

Saarilahti K, Kajanti M, Kouri M, Aaltonen L, Franssila K, Joensuu H (2003) Cyclin A and Ki-67 expression as predictors for locoregional recurrence and outcome in laryngeal cancer patients treated with surgery and postoperative chemotherapy. Int J Radiat Oncol Biol Phys 57: 986-995

Schnitt SJ (2001) Traditional and newer pathologic factors. J Natl Cancer Inst Monogr 30: $22-26$

Schraml P, Bucher C, Bissig H, Nocito A, Haas P, Wilber K, Seelig S, Kononen J, Mihatsch MJ, Dirnhofer S, Sauter G (2003) Cyclin E overexpression and amplification in human tumours. J Pathol 200: $375-$ 382

Sigurdsson H, Baldetorp B, Borg A, Dalberg M, Ferno M, Killander D, Olsson H (1990) Indicators of prognosis in node-negative breast cancer. $N$ Engl J Med 322: 1045 - 1053

Singletary SE, Allred C, Ashley P, Bassett LW, Berry D, Bland KI, Borgen PI, Clark G, Edge SB, Hayes DF, Hughes LL, Hutter RV, Morrow M, Page DL, Recht A, Theriault RL, Thor A, Weaver DL, Wieand HS, Greene FL (2003) Revision of the American Joint Committee on cancer staging system for breast cancer. J Clin Oncol 20: 3628-3636

Stendahl M, Kronblad Å, Ryden L, Emdin S, Bengtsson NO, Landberg G (2004) Cyclin D1 overexpression is a negative predictive factor for tamoxifen response in postmenopausal breast cancer patients. $\mathrm{Br} J$ Cancer 90: $1942-1948$

Syrjakoski K, Vahteristo P, Eerola H, Tamminen A, Kivinummi K, Sarantaus L, Holli K, Blomqvist C, Kallioniemi OP, Kainu T, Nevanlinna $\mathrm{H}$ (2000) Population-based study of BRCA1 and BRCA2 mutations in 1035 unselected Finnish breast cancer patients. J Natl Cancer Inst 92: $1529-1531$

Tommiska J, Eerola H, Heinonen M, Salonen L, Kaare M, Tallila J, Ristimaki A, von Smitten K, Aittomaki K, Heikkila P, Blomqvist C, Nevanlinna H (2005) Breast cancer patients with p53 PRO72-homozygous genotype have a poorer survival. Clin Cancer Res 11: 5098-5103

Torhorst J, Bucher C, Kononen J, Haas P, Zuber M, Köchli OR, Mross F Dieterich H, Moch H, Mihatsch MJ, Kallioniemi O-P, Sauter G (2001) Tissue microarrays for rapid linking of molecular changes to clinical endpoints. Am J Pathol 1599: 2249-2256

Wood G, Warnke R (1981) Suppression of endogenous avidin binding activity in tissues and its relevance to biotin-avidin detection systems. J Histochem Cytochem 29: 1196-1204 